Mikołaj Jazdon

\title{
Czerwiec 1956 wiosną 1981. Poznań 1956 (1981) Tadeusza Litowczenki i Mirosława Kwiecińskiego
}

W czerwcu 1981 r. Tadeusz Litowczenko zrealizował we współpracy z Mirosławem Kwiecińskim film dokumentalny Poznań $1956^{1}$. Wiele wskazuje na to, że był to pierwszy film podejmujący temat pamiętnego zrywu poznaniaków w czerwcu 1956 r. Wyprodukowany w poznańskim ośrodku TVP stanowi wyjątkowy zapis atmosfery, w jakiej prawda o tych dramatycznych wydarzeniach z powojennych dziejów Polski po raz pierwszy przebijała się do przestrzeni publicznej przez nieprzekraczalny od ćwierćwiecza mur milczenia. Dokument oparty na dwóch równoległych ciągach narracyjnych przeplata wypowiedzi świadków, uczestników wydarzeń z czerwca 1956 r. z kroniką wydarzeń skomponowaną $\mathrm{z}$ archiwalnych fotografii i komentarza zza kadru. Ważny kontekst

Poznań 1956, scenariusz i realizacja: Tadeusz Litowczenko i Mirosław Kwieciński, zdjęcia: Andrzej Półrolniczak, dźwięk: Andrzej Szalbierz, opracowanie muzyczne: Janusz Hojan, montaż: Róża Wojta, komentarz czyta: Tadeusz Drzewiecki, kierownictwo produkcji: Ireneusz Młynarczyk i Felicja Ryszka, konsultanci: doc. dr Zofia Trojanowicz, dr Aleksander Ziemkowski, Telewizja Polska, Poznań 1981, format zapisu: taśma światłoczuła $16 \mathrm{~mm}$, czarno-biały, czas trwania: $52^{\prime}: 53^{\prime \prime}$. 
dla powstania tego dzieła wyznacza książka Poznański Czerwiec 1956, wydana także w 1981 r., pod redakcją poznańskich polonistów i profesorów UAM, Jarosława Maciejewskiego i Zofii Trojanowiczowej.

Przygotowywany wiosną $1981 \mathrm{r}$. film nosił początkowo tytuł Czerwiec 56 (w scenariuszu) oraz Poznań - czerwiec 1956 (w scenopisie). Małgorzata i Marek Hendrykowscy, historycy badający dzieje filmu w Poznaniu, podają też tytuł Poznański Czerwiec '56 [Hendrykowska, Hendrykowski 1996: 292]. Jego telewizyjna emisja miała odbyć się w czasie obchodów dwudziestopięciolecia dramatycznych wydarzeń poznańskiego Czerwca. Najprawdopodobniej film został wyemitowany w paśmie lokalnym (udało się to ustalić po rozmowach z twórcami filmu - Litowczenką, Kwiecińskim oraz Różą Wojtą) ${ }^{2}$, co nie pozostało bez wpływu na jego ograniczony rezonans. W czasie stanu wojennego trójka wymienionych realizatorów ukryła dodatkową kopię filmu (wykonaną nieoficjalnie przez Litowczenkę w stołecznym laboratorium TVP) w jednym z pomieszczeń poznańskiego ośrodka telewizyjnego. Oryginał filmu zaginął $w$ warszawskim archiwum TVP. Nie można wykluczyć, że został celowo zniszczony, biorąc pod uwagę dramatyczne losy innego filmu dokumentalnego o tej samej tematyce, czyli Niepokonanych (1984, 70') A. Marka Drążewskiego 3 , a także

W czasie przygotowywania tego artykułu rozmawiałem z twórcami filmu: Litowczenką, Kwiecińskim i Wojtą. Chciałbym podziękować im za poświęcony czas i udzielone informacje. Osobno pragnę podziękować paniom Katarzynie Janysce-Cyris i Mirosławie Hajdrowskiej, z poznańskiego ośrodka TVP, za umożliwienie mi obejrzenia pierwotnej wersji filmu Poznań 1956.

Mariusz Guzek pisał o Niepokonanych: „Film powstawał bardzo długo, między 1981 a 1984, i poprzedzony został 24-minutową introspekcją w postaci dokumentu o jednej z ofiar starć 28 czerwca 1956 roku, Romku Strzałkowskim, Jeszcze czekam, który został ukończony w 1982 roku. Te dwa dzieła powstały, jako jedne z pierwszych, w Studiu Filmowym im. Karola Irzykowskiego. Zarówno jeden, jak i drugi obraz przez większą część dekady skazane były decyzją władz partyjnych na leżakowanie na półkach. Ponadto Niepokonani to prawdopodobnie jedyny polski film, który usiłowano fizycznie zniszczyć. W roku 1982, kiedy zmontowany czekał na ostatnią fazę postprodukcji, został dosłownie wyniesiony na śmietnik. Później Marek Drążewski i montażystka Małgorzata Rodowicz odnaleźli część rolek w zakładach fototechnicznych w Kielcach, gdzie z celuloidowego dokumentu odzyskiwano srebro i plastik, część w zakładach w Radzewie, po części 
fakt zaginięcia taśmy z dźwiękiem do filmu Romek Strzałkowski (1981, produkcja: Zespół Reporterów i Dokumentalistów Fakt) autorstwa Litowczenki.

Wcześniej, już podczas kolaudacji w czerwcu 1981 r., Poznań 1956 spotkał się z ostrą krytyką ze strony przedstawicieli telewizji zasiadających w komisji oceniającej powstały film ${ }^{4}$. Realizatorzy zostali zobowiązani do nakręcenia i włączenia do filmu wywiadu z pułkownikiem mo Stanisławem Biczysko, pełniącym funkcję komendanta poznańskiej milicji w czerwcu 1956 r. Autorzy nie uzyskali też zgody na wysłanie filmu na Ogólnopolski Festiwal Filmów Krótkometrażowych w Krakowie, co pozbawiło go możliwości dotarcia do opiniotwórczego środowiska polskich krytyków, nie wspominając o szansie na festiwalowe wyróżnienia, na jakie obraz ten mógł liczyć, biorąc pod uwagę jego tematykę oraz kształt formalny. Poznań 1956 został pokazany dopiero w październiku 1990 r. na zorganizowanym w Łódzkim Domu Kultury pierwszym Festiwalu Mediów „Człowiek w zagrożeniu”. Jednak wówczas znane były już filmy wspomnianego wyżej Drążewskiego: oprócz Niepokonanych Jeszcze czekam $(1982)^{6}$ o Romku Strzałkowskim, a dzień przed pokazem filmu Litowczenki i Kwiecińskiego festiwalowa publiczność obejrzała Zmęczonych dyktatura. Poznań - czerwiec-1956 (1990), sześćdziesięciodwuminutowy dokument Anny Górnej i Lubomira Zająca z łódzkiej Wytwórni Filmów Oświatowych, także podejmujący temat poznańskiego Czerwca. Realizację zdjęć do tego ostatniego, rozpoczętą jesienią 1981 r., przerwało

zmontowanego filmu nie pozostał nawet najmniejszy ślad. Ocalała jednak kopia negatywowa, dzięki której można było w 1984 roku przystąpić do ponownego montażu" [Guzek 2010: 258-259].

4 Przebieg kolaudacji znam z relacji Litowczenki i Kwiecińskiego. Ten ostatni zapamiętał słowa jednego z członków komisji kolaudacyjnej, byłego korespondenta TVP w Moskwie: „Towarzysze, to jest najlepszy film, jaki widziałem, ale nie ośmieliłbym się umieścić go na antenie”.

5 W 1988 r. Niepokonani otrzymali Nagrodę Don Kichota Polskiej Federacji DKF podczas Lubuskiego Lata Filmowego w Łagowie oraz I Nagrodę na Festiwalu Filmów Społeczno-Politycznych w Łodzi.

6 Wyrazem uznania środowiska filmowego dla dokumentu Drążewskiego, krótko po jego powstaniu, była Nagroda Don Kichota przyznana przez Polską Federację DKF W 1982 r. 
wprowadzenie stanu wojennego. Autorzy ukończyli go dopiero w 1990 r. Warto również wspomnieć o niezrealizowanym scenariuszu dokumentu pod nieomal takim samym tytułem, co film Litowczenki i Kwiecińskiego. Prof. Piotr Zwierzchowski natrafil w październiku 2016 r. w Archiwum Akt Nowych w Warszawie na dokumentację dotyczącą pełnometrażowego filmu dokumentalnego Poznań 56. Jego scenariusz, noszący datę powstania 1981, napisali Paweł Kędzierski i Andrzej Chodakowski.

Poznań 1956 Litowczenki i Kwiecińskiego na ponowne odkrycie musiał czekać do roku 2006. Jednak wówczas TVP zażądała skrócenia filmu, by dopasować jego długość do czasu antenowego przydzielonego na emisję. W efekcie pokazana wówczas i emitowana w kolejnych latach wersja jest o około 12 minut krótsza od oryginalnej i trwa 41 minut $^{8}$ (wersja pierwotna ma 52':53"). Ten smutny fakt wiele mówi o sytuacji samego filmu, przez lata nieznanego, zapomnianego, niedocenionego. Trudno bowiem sobie wyobrazić, aby od spełnienia podobnych warunków TVP uzależniała pokazanie filmów wyprodukowanych później niż dzieło poznańskich autorów, ale za to bardziej znanych, jak wspomniane dokumenty Drążewskiego oraz Górnej i Zająca. Emisję skróconej wersji Poznania 1956 poprzedzono słowem wstępnym Litowczenki?. lenie się ze mną tym odkryciem i udostępnienie mi fotokopii scenariusza.

Z krótszej wersji, opracowanej w 2006 r., usunięto sceny z wypowiedziami anonimowego mieszkańca ulicy Młyńskiej oraz doc. dra Henryka Karonia, fragmenty z wypowiedzi Egona Naganowskiego i Włodzimierza Marciniaka, a także scenę mówiącą o śmierci kaprala UB Zygmunta Izdebnego.

9 Reżyser mówił w nim o trudnych kolejach losu tego filmu: „Dwadzieścia pięć lat temu powstał dokument o Czerwcu. Film miał podwójne życie. Żył życiem naszym, autorów, znaczy moim myśleniem i myśleniem współpracownika mojego, Mirosława Kwiecińskiego, a również życiem ludzi, którzy decydowali o tym, jak ma wyglądać telewizja, i ich zwierzchników. Różne rzeczy się działy z tym filmem. Oglądano go bez naszego udziału. Po prostu robiono jakieś kolaudacje, poprawki. Na przykład w komentarzu słowo «demonstranci» trzeba było zastąpić słowem «tłum». W ostatniej chwili, przed emisją, nagle trzeba było nagrywać wypowiedź pułkownika Biczysko z Milicji Obywatelskiej, który w pięćdziesiątym szóstym roku był po prostu komendantem policji. On mówił o odczuciach ludzi, tych, którzy byli w gmachu, którzy strzelali. Dziwne losy miał 
Jarosław Maciejewski, współautor - razem z Zofią Trojanowiczową - głośnej książki Poznański Czerwiec 1956, opublikowanej W 1981 r., pisał o kurtynie milczenia unoszącej się nad pamięcią o tragicznych wydarzeniach sprzed dwudziestu pięciu lat [Maciejewski 1990: 36]. Książka poznańskich polonistów przerywała to milczenie. Stanowiła też źródło wiedzy historycznej, z którego skorzystali twórcy filmu jeszcze na etapie powstawania publikacji. Ponadto doc. dr hab. Trojanowiczowa razem z drem Aleksandrem Ziemkowskim, autorem zamieszczonej w Poznańskim Czerwcu 1956 chronologicznej rekonstrukcji wydarzeń, figurują w napisach końcowych do filmu jako jego konsultanci naukowi. Porównując konstrukcję filmu i zawartość książki, można wskazać kilka punktów stycznych. Większość bohaterów filmu (Stanisław Matyja, Edmund Taszer, Egon Naganowski, Jan Fichna, Henryk Karoń i Aleksandra Banasiak) to autorzy wspomnień opublikowanych w Poznańskim Czerwcu 1956.

Zamieszczony w nim rozdział Próba chronologicznej rekonstrukcji wydarzeń [Ziemkowski 1990, 56-110], dostępny twórcom w wersji maszynopisu, można uznać za istotny punkt odniesienia dla jednego z dwóch głównych ciągów narracyjnych filmu. Został on zbudowany z archiwalnych fotografii (część z nich zamieszczono w książce) dokumentujących powstanie poznańskie (termin stosowany przez Ziemkowskiego we wspomnianym rozdziale) oraz tekstu komentarza czytanego zza kadru przez Tadeusza Drzewieckiego (aktora Teatru Nowego w Poznaniu) ${ }^{10}$. Komentarz prezentuje chronologiczną relację z wydarzeń z 28-30 czerwca, 27 września i 19-21 października 1956 r. Najbardziej rozbudowany

po prostu ten film. W stanie wojennym oryginał zaginął. Kopię, wspólnie z montażystą, Różą Wojtą, schowaliśmy w jej szafie ze ścinkami filmowymi, przykrytą jakimiś papierami, kartonami. I tak się zachowała ta kopia i dzięki temu możecie obejrzeć państwo ten film. Zapraszam”.

W 1981 r. aktor wystąpił w jednej z ról w głośnym spektaklu Izabeli Cywińskiej i Janusza Michałowskiego Oskarżony: Czerwiec Pięćdziesiątsześć (premiera w Teatrze Nowym odbyła się 20 czerwca 1981 r.). W 2007 r., podczas viI Festiwalu Teatru Polskiego Radia i Teatru Telewizji „Dwa Teatry” w Sopocie Drzewiecki został uhonorowany nagrodą za najlepszą rolę męską w słuchowisku Czarny czwartek (2006), według scenariusza i w reżyserii Roberta Mirzyńskiego z Radia Merkury w Poznaniu. 
fragment dotyczy tego, co działo się w Poznaniu 28 czerwca, a wchodzące $w$ jego skład sekwencje anonsowane są planszami z podaną godziną opisanych $\mathrm{w}$ nich zdarzeń. W podobny sposób, z podziałem na godziny, przedstawił kronikę Czarnego Czwartku Ziemkowski w swoim opracowaniu. Chronologiczny opis wydarzeń, pieczołowicie skomponowany z fotografii „ożywionych” za pomocą ruchów kamery filmującej zdjęcia (repollero), montażowych zestawień, muzyki i słów komentarza, stanowi poruszającą w swej lapidarności opowieść kronikarza dziejów najnowszych. Jej forma nawiązuje do zrodzonej na początku lat 6o. tradycji polskiego filmu dokumentalnego ze zdjęć [Jazdon 2006] i takich utworów jak Album Fleischera (1962) Janusza Majewskiego czy Pamięć tamtych dni (1968) Ireny Kamieńskiej, korzystających $\mathrm{z}$ fotografii jako podstawowego materiału wizualnego. Za sprawą filmu Litowczenki i Kwiecińskiego historyczne zdjęcia z poznańskich ulic, wykonane w dniach czerwcowych wydarzeń 1956 r., po raz pierwszy zostały przekopiowane na taśmę filmową, by za pośrednictwem telewizji dotrzeć do tysięcy telewidzów.

W Poznaniu 1956 sekwencje fotografii z komentarzem zza kadru przeplatane są scenami przedstawiającymi świadków i uczestników czerwcowego zrywu. W miejscach historycznych wydarzeń opowiadają oni przed kamerą o przeszłych zdarzeniach. Słowem, gestami i spojrzeniami rekonstruują przywołane z pamięci sytuacje. Właśnie te sceny stanowią o wyjątkowości filmu, nadają mu wymiar szczególnego świadectwa, a ich siła emocjonalnego oddziaływania nie osłabła z upływem lat, nabrała co najwyżej innego charakteru. Film przedstawia wydarzenia z punktu widzenia powstańców, co - biorąc pod uwagę czas realizacji obrazu - jest już samo przez się faktem bez precedensu. Przed kamerą pojawiają się uczestnicy i świadkowie protestu: Stanisław Matyja, Włodzimierz Marciniak i Andrzej Górny, a także Egon Naganowski, Edmund Taszer, Jan Fichna oraz pracownicy służby zdrowia ze szpitala im. Raszei: pielęgniarka Aleksandra Banasiak i lekarz doc. dr Henryk Karon.

W pierwotnej wersji filmu inną stronę niż powstańcza reprezentowali dawny dyrektor poznańskiego więzienia na Młyńskiej, Marian Lewandowski (scena z jego udziałem znajduje się też 
w wersji skróconej), oraz anonimowy obserwator szturmu na więzienie, mieszkaniec kamienicy położonej vis-à-vis więziennego gmachu (fragment z jego wypowiedzią został usunięty z krótszej wersji filmu). Dokręcony i dodany po wspomnianej kolaudacji fragment $\mathrm{z}$ rozmową $\mathrm{z}$ dawnym komendantem MO $\mathrm{w}$ Poznaniu w niczym nie osłabia pierwotnego zamiaru twórców, a wręcz go wzmacnia.

Dzieje się tak między innymi za sprawą dokonanego w filmie podziału na dwie przestrzenie wydarzeń. Przestrzenią protestujących i walczących są ulice. To przestrzeń otwarta, pokazana na archiwalnych fotografiach i w nakręconych w miejskich plenerach wywiadach, współbrzmiąca z narracją o walce o wolność. Przestrzenią drugiej strony konfliktu, czyli władzy i przedstawicieli jej organów, są wnętrza ukryte za oknami publicznych budowli. Właśnie oknom przyznano w Poznaniu 1956 symboliczne znaczenie. Ludzie władzy i beneficjenci panującego systemu skrywają się tu za oknami miejskich gmachów. W stronę tychże okien protestujący kierują swe spojrzenia, a potem broń.

W jednej ze scen filmu Stanisław Matyja, należący do grona najbardziej znanych uczestników poznańskiego zrywu, stoi, podpierając się kulami, na chodniku przy ulicy Armii Czerwonej (dziś ulica Święty Marcin), w pobliżu niewidocznego na ekranie budynku Akademii Muzycznej. Kamera, podążając za słowem i gestem świadka, kieruje obiektyw w stronę budynku Urzędu Komitetu Wojewódzkiego PZPR. Ruch transfokatora zawęża pole oglądu, zbliżając się do okien gmachu. Matyja mówi o wzburzeniu manifestantów zebranych na placu Mickiewicza na wieść o luksusowych towarach, jakimi otoczeni byli przebywający w gmachu KW członkowie rządzącej partii. Ów najazd kamery na okno urzędu tworzy w filmie pretekst do przejścia w opowiadaniu do sekwencji archiwalnych fotografii pokazujących robotników już po wejściu do siedziby poznańskiego PZPR. Jednocześnie wspomniane filmowe ujęcie okien partyjnej siedziby, wykonane wiosną $1981 \mathrm{r}$., zestawione ze słowami Matyi o skrywanych za nimi dobrach, służących uprzywilejowanej władzy, jest czymś więcej niż tylko relacją z przeszłości, kryje w sobie aluzję do współczesności. Dysproporcja między warunkami życia działaczy komunistycz- 
nej władzy a zwykłych obywateli, takich jak stojący przed kamerą robotnik o kulach, nie została zniwelowana. Choć sugestia ta nie jest w filmie wyrażona jednoznacznie, to pozostaje wyczuwalna, jako zamierzona uwaga twórców, przekazana za pośrednictwem filmowych środków wyrazu - ruchu kamery, zawartości kadru, montażowego zestawienia tego ujęcia $\mathrm{z}$ odpowiednimi słowami z wypowiedzi Matyi. Film zresztą zawiera o wiele więcej aluzji do polskich realiów z wiosny 1981 r., o czym będzie jeszcze mowa.

Człowiekiem zza okna, reprezentującym stronę władzy, jest w filmie pułkownik milicji, Stanisław Biczysko. Pojawia się on po scenie z udziałem Andrzeja Górnego, który, stojąc na ulicy Kochanowskiego, opowiada o toczonych w tym miejscu walkach manifestantów z ostrzeliwującą się z gmachu wUBP załogą. Tu także najazd kamery na jedno z okien gmachu stanowi pretekst do przejścia od sceny z Górnym do sceny z oficerem Mo, ubranym po cywilnemu (podobnie jak tajni funkcjonariusze sB). Biczysko siedzi na tle zasłoniętego firanką okna (wzmacnia to wrażenie „tajności” miejsca i odizolowania od świata za oknem), w swej wypowiedzi, ważąc słowa, bierze w obronę walczących ubowców. I znów w tej sekwencji - złożonej ze sceny z Górnym (na ulicy) i pułkownikiem Biczysko (w pokoju urzędu) - obok relacji historycznej pojawia się znaczący wizerunek współczesności. Górny opowiada o walkach toczonych na ulicy Kochanowskiego, stojąc w tym samym miejscu ćwierć wieku później. Dawna siedziba UB nadal służy tajnym PRL-owskim służbom noszącym teraz nazwę Służba Bezpieczeństwa. W tle za plecami Górnego widać czarną wołgę z dwoma mężczyznami w środku. Trudno nie pomyśleć, że to tajniacy zatrudnieni w miejscu, które w czerwcu 1956 r. zyskało ponurą sławę. Litowczenko zapamiętał, że w czasie realizacji zdjęć do tej sceny ekipę filmową fotografowano z okien urzędu. Komentator przedstawia zza kadru Biczysko jako pułkownika i doktora. Oficer prezentuje się zatem jako człowiek w zupełnie innej kondycji życiowej niż Matyja o kulach czy leżący na szpitalnym łóżku Taszer (wrócę do tego wątku później). Awansował, zdobył tytuł naukowy doktora. Staje w obronie strony rządowej, ale sam nie ujawnia, jaką odgrywał rolę w czasie, gdy dokonywał się dramat zbuntowanego miasta. 
Trzecim znaczącym oknem z filmu jest to z kamienicy przy ulicy Młyńskiej, gdzie mieszka nieprzedstawiony z imienia i nazwiska świadek powstańczego szturmu na więzienie. Wygodnie rozpostarty $\mathrm{w}$ fotelu starszy mężczyzna siedzi na tle okna, za którym widać wejście do gmachu sądu. „Wypadki na Młyńskiej w pięćdziesiątym szóstym widziałem z własnego okna” - rozpoczyna swą relację. Nie ujawnia w niej w sposób jednoznaczny stosunku do wydarzeń, których był świadkiem. Najpierw mówi o ładzie i porządku panującym w gromadzie ludzi oblegających więzienie, ale chwilę później ze szczegółami opowiada o plądrowaniu sądowych pomieszczeń i pobliskiego sklepu spożywczego. Opis ten, którego nie można zanegować jako niezgodnego z faktami, wpisuje się jednak w tonację wstrzemięźliwej krytyki, współbrzmiącą z wypowiedzią pułkownika Biczysko.

W kolejnej scenie znów jesteśmy na ulicy, ale wydarzenia ze szturmu na więzienie przy Młyńskiej relacjonuje już jeden z jego uczestników, Włodzimierz Marciniak („Cały tłum skandował: dosyć bezprawia, niewoli, kajdan i tak dalej, tak dalej. Następną sprawą po rozbrojeniu tych strażników - całą tą broń przechowaliśmy po drugiej stronie ulicy w tej bramie"), wydelegowany przez powstańców do prowadzenia rozmów z dyrektorem więzienia. Wypowiedź tego ostatniego słyszymy w następnej scenie. Czarna sylwetka mówiącego odcina się tu na tle jasnej plamy zakratowanego okna (sic!). Lewandowski przedstawia swoją wersję wydarzeń niejako anonimowo. Jego twarzy nie widać, nieoświetlona tonie w mroku, nie zostaje też przedstawiony z nazwiska, inaczej niż większość pozostałych bohaterów filmu. Widz śledzi jego gesty, ruchy głowy, słucha tego, co mówi.

W trakcie przeprowadzonych przeze mnie rozmów z autorami filmu okazało się, że były dyrektor więzienia nie zgodził się wystąpić przed kamerą. Pozwolił za to nagrać rozmowę na taśmie magnetofonowej. W rezultacie w opisanej powyżej scenie wystąpił Mirosław Kwieciński. Słuchając odtwarzanego nagrania z wypowiedzią Lewandowskiego, dopasował się swym zachowaniem do tekstu, by zestawiony na montażu obraz i dźwięk wypadły przekonująco. W rzeczy samej, widz nieznający okoliczności powstania tej sceny nie domyśli się, że na ekranie ogląda kogoś innego niż dyrektor więzienia. 
Ostatnim znaczącym oknem w tym konsekwentnie budowanym w filmie łańcuchu opozycji: przestrzenie - wnętrza jest okno w budynku poznańskiej rozgłośni radiowej przy ulicy Berwińskiego. W jej siedzibie w czerwcu 1956 r. ówczesny premier, Józef Cyrankiewicz, wygłosił słynne przemówienie zawierające groźbę srogiego rozprawienia się z przeciwnikami władzy. Kamera najpierw pokazuje budynek rozgłośni w planie ogólnym, niejako w całej okazałości, po czym następuje najazd transfokatorem na jedno z wyżej położonych okien, a potem przejście, po cięciu montażowym, do wnętrza studia nagrań. W pustej scenerii historycznego miejsca oglądamy ściany, stól, telefon i mikrofon. Pojawia się fotografia Cyrankiewicza. Zza kadru słychać odtwarzane $\mathrm{z}$ archiwalnych nagrań przemówienie premiera.

Zestawienie dźwiękowego zapisu z historycznymi rekwizytami należy do konwencji filmu dokumentalnego. W tym wypadku niesie także określone dodatkowe znaczenia, odnoszące się do epoki karnawału Solidarności, gdy film był kręcony, a nie wyłącznie do wydarzeń z czerwca 1956 r. Cyrankiewicz pojawia się tu jedynie „pod postacią” fotografii i odtwarzanego z magnetofonu głosu. Podobnie jak dyrektor więzienia na Młyńskiej nie staje przed kamerą, choć w 1981 r. żył jeszcze i pełnił funkcje publiczne. Mniej istotne wydaje się pytanie, czy autorzy filmu starali się do niego dotrzeć i zaproponować udział w filmie. Być może odmówiłby, świadom roli, jaką wówczas odegrał, oraz jej niekorzystnego wydźwięku, bowiem latem 1981 r. musiała być odbierana szczególnie negatywnie. Istotny i znaczący jest za to sam zabieg zredukowania obecności ludzi władzy do kilku statycznych fotografii i garści cytatów zza kadru".

Pod sam koniec filmu, w sekwencji zatytułowanej 19-21 października, oglądamy gazetowe reprodukcje fotografii nowych władz partyjnych z Władysławem Gomułką na czele, a w jednej z wcześniejszych scen umieszczono zdjęcie Edwarda Gierka. przeprowadzić przed kamerą rozmowy z Cyrankiewiczem i innymi przedstawicielami ówczesnej władzy, co wiązało się z zamiarem przedstawienia w filmie ich punktu widzenia. 
W 1956 r. reprezentował w Poznaniu władzę, która wysłała na ulice Poznania czołgi, a w czerwcu 1981 r., pozbawiony funkcji pierwszego sekretarza PZPR, utożsamiany był z epoką, która - jak się wówczas wydawało - odchodziła nieodwołalnie w przeszłość, ustępując miejsca zmianom, jakie niósł ruch solidarnościowy.

Scena z przemówieniem Cyrankiewicza została efektownie zmontowana $\mathrm{w}$ filmie z następną, pokazującą groby ofiar poznańskiego Czerwca. Groźne i butne słowa premiera o odrąbywaniu ręki podniesionej na władzę ludową zyskało $\mathrm{w}$ filmie ponure dopełnienie w postaci cmentarnych krzyży i listy poległych, włączonej $\mathrm{w}$ tę sekwencję $\mathrm{w}$ formie czarnej planszy $\mathrm{z}$ białymi napisami.

Okna i skrywające się za nimi wnętrza, oznaczające w Poznaniu 1956 przestrzenie ludzi władzy (chodzi przede wszystkim o sceny nakręcone w 1981 r., sekwencje fotograficzne oddziałują w inny sposób, stanowią niejako wprowadzenie i tło rozmów przed kamerą), zajmują w filmie mniej miejsca, plasują się niejako na dalszej pozycji niż sceny plenerowe ze świadkami historycznych wydarzeń, odtwarzającymi przed kamerą, słowem i gestem, przeszłe zdarzenia.

Poznań 1956 przyjmuje formę swego rodzaju wizji lokalnej, służącej odtworzeniu przebiegu zbrodni dokonanej na zbuntowanym mieście ćwierć wieku wcześniej ${ }^{12}$. Litowczenko i Kwieciński dokonali wiosną 1981 r. rzeczy wyjątkowej. Wychodząc w przestrzeń miasta z kamerą i mikrofonem, zorganizowali szczególnego rodzaju performance z udziałem uczestników i świadków poznańskiego zrywu z 1956 r. Konkretne miejsca będące nośnikami pamięci historycznej ${ }^{13}$, jednak przez lata utajnionymi, zakazanymi

Warto wspomnieć, że w styczniu 1981 r. wszedł na ekrany polskich kin film fabularny Filipa Bajona Wizja lokalna 1901 (1980), rekonstruujący przebieg słynnego strajku szkolnego polskich dzieci we Wrześni w zaborze pruskim na początku xx stulecia. Film Bajona oraz dokument Litowczenki i Kwiecińskiego wpisują się w szersze zjawisko rekonstruowania w kinie przedstawień konkretnych wydarzeń historycznych o szczególnym znaczeniu dla krajowego odbiorcy w chwili realizacji i prezentacji gotowych utworów.

„Tylko część potencjalnych nośników pamięci, jakie pojawiały się i pojawiają się w historii, staje się nośnikami aktywnymi. To dopiero my, ludzie współcześni, przyznajemy im tę rolę - bądź za jakiś czas uczynią to nasi następcy. Nośnik będzie aktywny, dopóki ktoś będzie go zauważał” [Kula 2002: 45]. 
i wykluczonymi z oficjalnego dyskursu społecznego i politycznego, odzyskały swe znaczenie. Pozbawieni przez lata możliwości dania świadectwa, opowiedzenia o swym doświadczeniu dawni manifestanci i powstańcy mogli - dzięki obecności kamery i pod osłoną działającej oficjalnie ekipy filmowej - po raz pierwszy otwarcie pojawić się na ulicy Kochanowskiego, Młyńskiej, czy placu Mickiewicza, by właśnie w tych miejscach opowiedzieć o swym udziale w powstaniu. Obecni niczym świadkowie wizji lokalnej w miejscach nie tak w końcu odległych w czasie wydarzeń, za to trwale wpisanych w ich pamięć i często rzutujących na ich dalsze losy, odtwarzają przed kamerą przeszłość. Wskazują konkretne miejsca, gestami, ruchami, spojrzeniami, w szczątkowej formie odtwarzają swe dawne zachowanie.

Egon Naganowski, stojąc na balkonie mieszkania przy ulicy Kochanowskiego, opowiada o tym, co widział: o maszerującym tłumie poznaniaków, ofiarach padających od kul, zakrwawionej fladze narodowej, śmierci Romka Strzałkowskiego, najbardziej pamiętnej ofiary poznańskiego dramatu. Wreszcie wspomina moment, w którym sam został trafiony kulą w ramię:

Potem zjawiły się dwie młode dziewczyny, ja mówiłem: co wy tu robicie? - z torbą czerwonego krzyża. - My jesteśmy powstańcza służba sanitarna. Zdziwiłem się. Poczułem się zupełnie jak podczas powstania warszawskiego. No i potem mnie dwóch panów zaniosło na dół tutaj na Dąbrowskiego i zawieźli mnie do szpitala Raszei i tam mnie położyli. Położyli w pokoju od ulicy na parterze. Od razu poszła seria i my pod łóżka i tak żeśmy się wyczołgali na korytarz.

Cytowany fragment z końcowej części relacji Naganowskiego w sposób najbardziej dobitny przyrównuje wydarzenia z czerwca 1956 r. do powstańczego zrywu (obecny jest tylko w pełnej wersji filmu), odnajdziemy go także w spisanej relacji pisarza zamieszczonej w książce Poznański Czerwiec 1956 ${ }^{14}$.

14 „Nagle poczulem uderzenie w bark i stojąca w pobliżu mnie siostra znajomej dentystki krzyknęła przerażona: «Ależ pan jest ranny!» Od chwili, gdy znalazłem 
Podobne emocjonujące relacje $\mathrm{z}$ walk ulicznych przedstawiają Górny (na ulicy Kochanowskiego, przed gmachem wUBP) i Marciniak (na ulicy Młyńskiej, przed bramą do więzienia). Szczególną siłę wyrazu ma scena nakręcona z udziałem Aleksandry Banasiak, pielęgniarki ze szpitala Raszei, która niosła pomoc rannym. Ubrana w pielęgniarski czepek (potęguje to wrażenie wejścia w rolę sprzed lat) wskazuje na miejsca konkretnych zdarzeń - okno, zza którego usłyszała wołanie o pomoc, czy bramę, w której znalazła ciężko rannego mężczyznę. Sfilmowana na czarno-białej taśmie kałuża w miejscu, gdzie padł postrzelony w brzuch dwudziestolatek, wygląda jak rozległa plama krwi, która mimo upływu lat nie wyschła. Wrażenie oglądania miejsc, w których czas jakby stanął, towarzyszy odbiorowi również innych momentów z filmu. Pejzaż ulic Poznania nie zmienił się radykalnie w latach 1956-1981, a uczestnicy powstania nie zdążyli się jeszcze zestarzeć, co wzmacnia siłę emocjonalnego oddziaływania filmowej rekonstrukcji.

W jednej z ostatnich scen Matyja opowiada o chwili swego aresztowania. Stoi w słabo zabudowanym krajobrazie na tle parterowego budynku. Tu mieszkał w czerwcu 1956 r. Drobna sylwetka starszego człowieka, podpierającego się kulami, stojącego w ubogim krajobrazie, ukazuje się nagle w wyobraźni słuchacza jego relacji w otoczeniu samochodów pancernych i tłumu wojska wysłanego po niego przez władzę („Jak mnie wyprowadzili, to im powiedziałem, że gangstera gorzej nie biorą - największego w Ameryce - jak mnie zabrano"). Wkrótce po powstaniu filmu to miejsce i ów historyczny pejzaż uległy diametralnemu przekształceniu, zabudowane wieżowcami nowego osiedla Rataje. Upływający czas przydał wartości filmowemu zapisowi.

się na balkonie, minęło bodaj nie więcej niż 40 minut. Zaprowadzono mnie do pokoju, gdzie zadziwiająco szybko zjawily się dwie dziewczyny, które przedstawiły się jako «powstańcza służba sanitarna» (zupełnie jakby przyfrunęły z dni powstania warszawskiego), ściągnęły mi marynarkę i założyły prowizoryczny opatrunek, a potem dwaj mężczyźni zanieśli mnie - choć chciałem iść o własnych siłach - przez jakieś mieszkanie na inną klatkę schodową, wychodzącą na ul. Dąbrowskiego. Tam, już na ulicy, musieli się z trudem przepychać przez tłum, wołając: «Uwaga, niesiemy rannego!»” [Naganowski 1990: 274]. 
Dwa wspomniane powyżej elementy wyglądu głównych bohaterów filmu - czepek pielęgniarski Aleksandry Banasiak i kule Stanisława Matyi - współbrzmią z jeszcze jednym motywem filmu. Można go nazwać szpitalnym. Pierwszą osobą wypowiadającą się przed kamerą jest Edmund Taszer, przewodniczący zakładowej delegacji HCP, która po raz pierwszy już w październiku $1955 \mathrm{r}$. wyjechała do Warszawy na rozmowy z przedstawicielami rządu na temat poprawy sytuacji bytowej robotników z zakładów Cegielskiego. Taszer nie zdaje swojej relacji w żadnym z miejsc związanych z wydarzeniami z Czarnego Czwartku. Siedzi w piżamie na szpitalnym łóżku w Instytucie Chorób Układu Nerwowego i Narządów Zmysłów (taka nazwa figuruje na tablicy z elewacji budynku pokazanego na początku tej sceny). Bohater powróci jeszcze w scenie z końca filmu (ciąg dalszy rozmowy zapisanej w szpitalu), by tym razem opowiedzieć, jak oskarżany i atakowany na partyjnym zebraniu za współudział w robotniczym proteście zemdlał i trafił do szpitala. Spoglądając na niego i przysłuchując się jego wypowiedzi z 1981 r., można odnieść wrażenie, że stan chorobowy, w jaki popadł Taszer w czerwcu 1956 r., nie minął, ale trwa nadal. Dochodzi tu do głosu nadbudowujący się w tle wymiar metaforyczny tych obrazów z filmu, w których pojawiają się przedmioty lub miejsca kojarzone z chorobą i leczeniem. Przebywający w szpitalu Taszer, poruszający się o kulach Matyja czy przechodząca w pielęgniarskim czepku ulicą Kochanowskiego Banasiak każą myśleć o Czerwcu '56 jako o niezagojonej ranie. Choć w 1981 r. minęło już dwadzieścia pięć lat, od kiedy została zadana, wciąż krwawi i boli.

Dopełnieniem tego motywu jest jeszcze jedna scena, nakręcona na korytarzach szpitala im. Raszei. Ubrany w biały lekarski kitel doc. dr Henryk Karoń opowiada o przyjmowaniu do szpitala rannych, którzy szybko wypełnili jego pomieszczenia. W pewnym momencie wspomina epizod $\mathrm{z}$ ciężko postrzelonym podchorążym. Gdy ten zaczął grozić rannym cywilom odwetem ze strony wojska za swoje cierpienie, lekarz interweniował, by nie doszło do rękoczynu ze strony oburzonego tłumu. „Wspominam ten epizod kończy Karoń - ponieważ zawsze mundur polskiego żołnierza stanowił pewnego rodzaju... był zawsze kultem dla naszego spo- 
łeczeństwa i zawsze stanowił wyraz najwyższego szacunku. To się wszystko zmieniło w ciągu tych kilku godzin”. Wypowiedź ta wskazuje na konkretny skutek wydarzeń z czerwca 1956 r. - trwałą utratę zaufania poznaniaków do wojska. Fakt odnotowany także przez historyka ${ }^{15}$. Karoń, wspominając zatem określony epizod sprzed dwudziestu pięciu lat, jednocześnie wskazywał na konkretne i odczuwalne współcześnie skutki ran zadanych poznańskiej społeczności.

Film Litowczenki i Kwiecińskiego, nakręcony w przededniu rocznicy poznańskiego zrywu, można było odczytać zarówno jako pierwszą (lub jedną z pierwszych) próbę opisania tamtych wydarzeń kamerą filmową, jak i opis współczesnego kontekstu, w jakim odradzała się w przestrzeni publicznej pamięć o przemilczanej historii miasta. Mówił zatem nie wprost o chorobie zakłamania i przemilczenia. Jednocześnie pokazując ludzi z odwagą i bez skrępowania opowiadających o minionym dramacie w przestrzeniach jeszcze rok wcześniej niedostępnych dla podobnych działań, ukazał znaczący wymiar zmian, jakie zaszły w społeczeństwie po sierpniu 1980 r. Dwaj świadkowie historii występujący przed kamerą - Naganowski i Michna (pracownik MTP opowiadający o tłumie demonstrantów, który dotarł na teren poznańskich targów) - noszą wpięte w klapy marynarek znaczki Solidarności. A tak brzmią ostatnie słowa komentarza z filmu: „Trzeba jednak było czekać dwadzieścia cztery lata, do sierpnia 1980 r. na wyciągnięcie pełnych wniosków z poznańskiej tragedii, na to, by siłę zastąpiły rozmowy i rozwiązania polityczne”.

Wymownym znakiem zmian zachodzących tu i teraz, wiosną 1981 r., jest scena stanowiąca ramę kompozycyjną filmu. Na początku utworu, przed pojawieniem się tytułu, przyglądamy

„Spora część poznańskiej kadry oficerskiej wyniosła z Czerwca 's6 poczucie moralnej krzywdy, zrodzone z niemożności wyjaśnienia mechanizmów rządzących wówczas wojskiem i jego wewnętrznym aparatem ucisku (informacja wojskowa, służby polityczne). Wynikiem tego była swoista izolacja społeczna, w której podchorążowie i kadra znaleźli się nie z własnej winy. W latach następnych zdarzały się przypadki nieprzychylności mieszkańców w stosunku do podchorążych. Wśród mieszkańców Poznania upadł autorytet żołnierskiego munduru wyniesiony z przedwojennej tradycji” [Karwat 2006: 68]. 
się sfilmowanej z góry ciężarówce ciągnącej na olbrzymich rozmiarów przyczepie podłużną konstrukcję, jakby przęsło mostu lub gigantycznych rozmiarów słup owinięty biało-czerwoną flagą. Samochód wolno przejeżdża przez zakładową bramę (z komentarza dowiadujemy się, że to Zakłady im. Hipolita Cegielskiego w Poznaniu) obleganą przez tłum ludzi. Dopiero w ostatniej scenie filmu, gdy obraz przewożonej konstrukcji powraca, zostaje ujawnione, że jest to element pomnika Poznańskiego Czerwca 1956 (widać tablicę $\mathrm{z}$ tą informacją). W tle rozbrzmiewa muzyka Roty. Jakaś kobieta odrywa się od tłumu, podchodzi do konstrukcji i kładzie na niej kwiaty, jakby to była laweta armatnia przewożąca szczątki poległego bohatera. Film kończy się obrazem wiezionych przez miasto elementów pomnika. Jego odsłonięcie podczas obchodów dwudziestej piątej rocznicy Czerwca '56 było ważnym i przełomowym momentem w dziejach przywracania zbiorowej pamięci historycznych wydarzeń. Sceny z montażu i odsłonięcia pomnika znalazły się w filmach kręconych w drugiej połowie $1981 \mathrm{r}$. Poznań 1956 Litowczenki i Kwiecińskiego powstał przed obchodami tejże rocznicy, na fali odsłaniania prawdy o wydarzeniach sprzed ćwierćwiecza. Choć w istotnej mierze utrudniono jego rozpowszechnianie, to sam fakt jego realizacji należy uznać za znaczące osiągnięcie. Jego autorzy dobrze wykorzystali nadarzającą się okazję ${ }^{16}$, by na fali zmian zachodzących w kraju po wydarzeniach sierpnia 1980 r., w chwili poluzowania kontroli cenzuralnej i przy milczącym przyzwoleniu władzy na podejmowanie tematów wcześniej zakazanych, nakręcić film o powstaniu poznańskim '56 i ludziach, którzy wiosną 1981 r. mogli po raz pierwszy publicznie i otwarcie w przestrzeni swego miasta powiedzieć prawdę o tym, co w tych miejscach przeżyli i widzieli dwadzieścia pięć lat wcześniej.

Gdyby Poznań 1956 dotarł w 1981 r. do szerszej publiczności i piszących o filmie, być może w jakiejś mierze przełamałby powszechnie panujące w tym czasie (przełom 1980 i 1981 r.) przekonanie, o tym, że polski film dokumentalny tamtej doby „(funkcjonujący w oficjalnym obiegu) nie dorasta do wymogów chwili, a jego twórcy nie są przygotowani na ewentualność filmowania w czasie chwilowego uwolnienia klimatu politycznego. Jakby marazm, zaobserwowany na przełomie lat siedemdziesiątych/osiemdziesiątych, trwał nadal” [Hučková 2015: 390]. 


\section{Bibliografia}

Guzek Mariusz (2010), „Niepokonani” A. Marka Drążewskiego jako źródto do dziejów Października 1956, w: Październik 1956 w literaturze i filmie, red. Mariusz Zawodniak, Piotr Zwierzchowski, Wydawnictwo Uniwersytetu Kazimierza Wielkiego, Bydgoszcz.

Hendrykowska Małgorzata, Hendrykowski Marek (1996), Film $w$ Poznaniu i Wielkopolsce 1896-1996, Ars Nova, Poznań.

Hučková Jadwiga (2015), Opowieści naocznego świadka. Kino pomiędzy wiosnami Solidarności, w: Historia polskiego filmu dokumentalnego (1945-2014), red. Małgorzata Hendrykowska, Wydawnictwo Naukowe UAM, Poznań.

Jazdon Mikołaj (2006), Fotografie w roli głównej, „Kwartalnik Filmowy”, nr 54-55, s. 212-230.

Kula Marcin (2002), Nośniki pamięci historycznej, Wydawnictwo DiG, Warszawa.

Karwat Janusz (2006), Pacyfikacja miasta, „Kronika Miasta Poznania”, nr 2, s. 55-73.

Maciejewski Jarosław (1990), Po dwudziestu pięciu latach, w: Poznański Czerwiec 1956, red. Jarosław Maciejewski, Zofia Trojanowiczowa, wyd. 2, Wydawnictwo Poznańskie, Poznań.

Naganowski Egon (1990), To, co widziałem, w: Poznański Czerwiec 1956, red. Jarosław Maciejewski, Zofia Trojanowiczowa, wyd. 2, Wydawnictwo Poznańskie, Poznań.

Ziemkowski Aleksander (1990), Próba chronologicznej rekonstrukcji wydarzeń, w: Poznański Czerwiec 1956, red. Jarosław Maciejewski, Zofia Trojanowiczowa, wyd. 2, Wydawnictwo Poznańskie, Poznań.

Mikołaj Jazdon

June 1956 in spring of 1981 . Poznań 1956 (1981) by Tadeusz Litowczenko and Mirosław Kwieciński

The article presents the making of the first documentary film depicting the traumatic events of the anticommunist uprising in Poznan in June 1956 as well as the difficult fate of the documentary after it had been completed. Its authors, Tadeusz Litowczenko and Mirosław Kwieciński, composed their Poznań 1956 (1981) of two interwoven narrative lines. Archive photographs with off screen commentary make the first narrative line while cinéma-vérité-like interviews with the participants of historical events make the other. The film analysis is aimed to underline the formal means employed in the film to present the opposing sites of 
the conflict. It also focuses on the historical context from the times when film was being made in the so called 'festival of Solidarity movement' in the early 1980 s.

Keywords: Poznań June 1956; Polish documentary film; history of television; archive photographs; censorship; Solidarity movement; Stalinism.

Mikołaj Jazdon - filmoznawca, pracuje w Katedrze Filmu, Telewizji i Nowych Mediów UAM. Autor książek Dokumenty Kieślowskiego (2002), Polskie kino niezależne (redaktor tomu, 2005) i Kino dokumentalne Kazimierza Karabasza (2009). Redaktor, razem z Katarzyną Mąką-Malatyńską, tomów Zobaczyć siebie. Polski film dokumentalny przełomu wieków (2011) i Pogranicza dokumentu (2012, tom współredagowany z Piotrem Pławuszewskim) oraz numeru specjalnego „Images” (2014, nr 24): 21st-century Documentary Film In East and Central Europe. Autor artykułów publikowanych w „,Kwartalniku Filmowym”, „Images”, „Kinie”, „Ekranach”, „Znaku”, „Czasie Kultury” oraz tekstów wydanych za granicą po angielsku, niemiecku, hiszpańsku, duńsku, czesku, słowacku. Ekspert Polskiego Instytutu Sztuki Filmowej od 2013 r. Autor opracowań do albumów z filmami DVD z serii Polska Szkoła Dokumentu (Krzysztof Kieślowski, Kazimierz Karabasz, Władysław Ślesicki, Czarna seria oraz Gryczełowska, Halladin, Kamieńska). Współautor scenariuszy do 12 odcinków telewizyjnej serii Sztuka dokumentu. Dyrektor artystyczny Międzynarodowego Festiwalu Filmów Dokumentalnych „Off Cinema” w Poznaniu. 


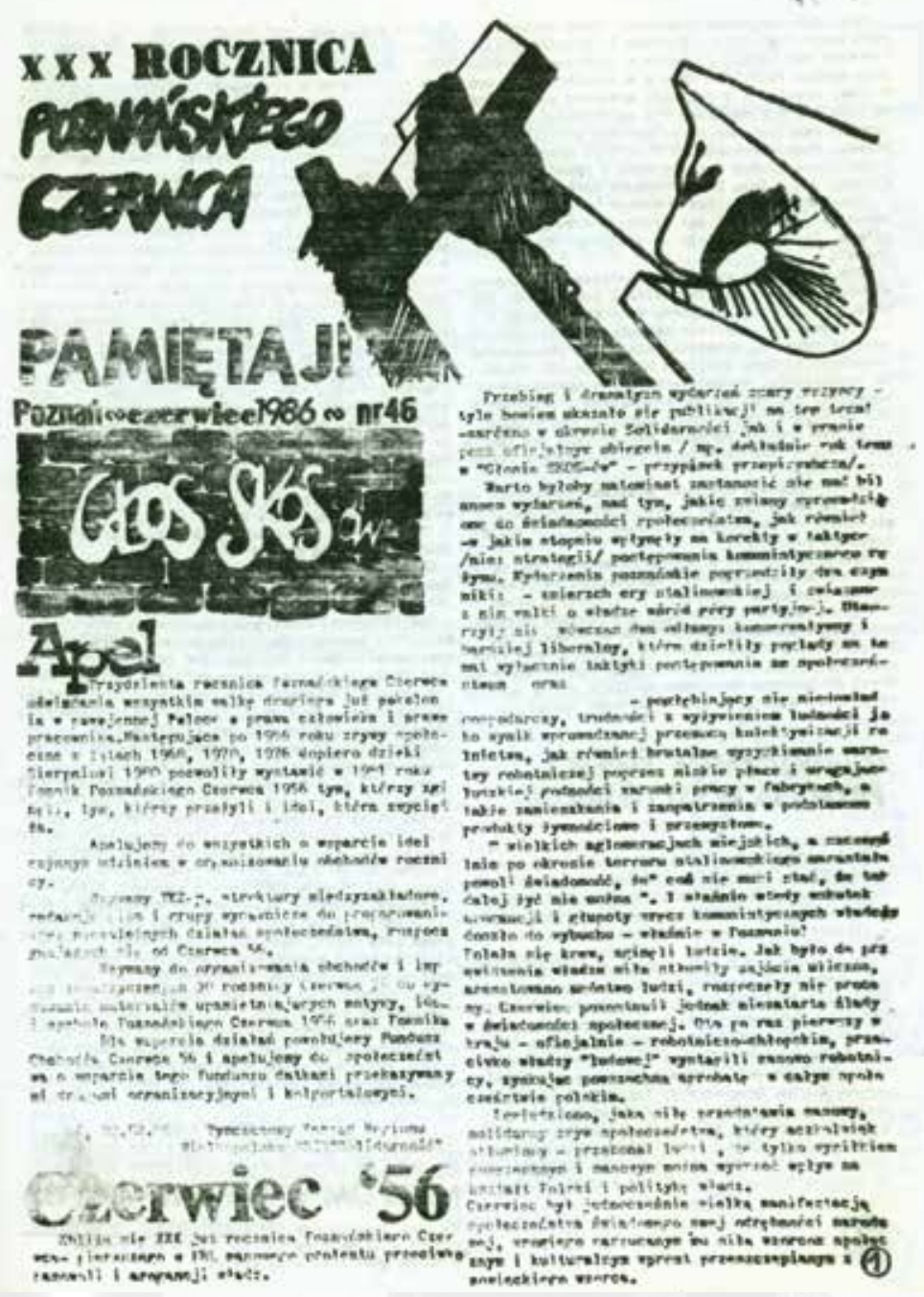

„Głos Skosów” 1986, nr 46 (wydany w trzydziestą rocznicę wydarzeń poznańskiego Czerwca). [skos - Szkolne Koła Oporu Społecznego, młodzieżowy ruch oporu powstały 13 marca 1982 r. w Poznaniu, w wyniku sprzeciwu wobec wprowadzenia stanu wojennego; w różnej skali działał w większości szkół średnich Poznania] 


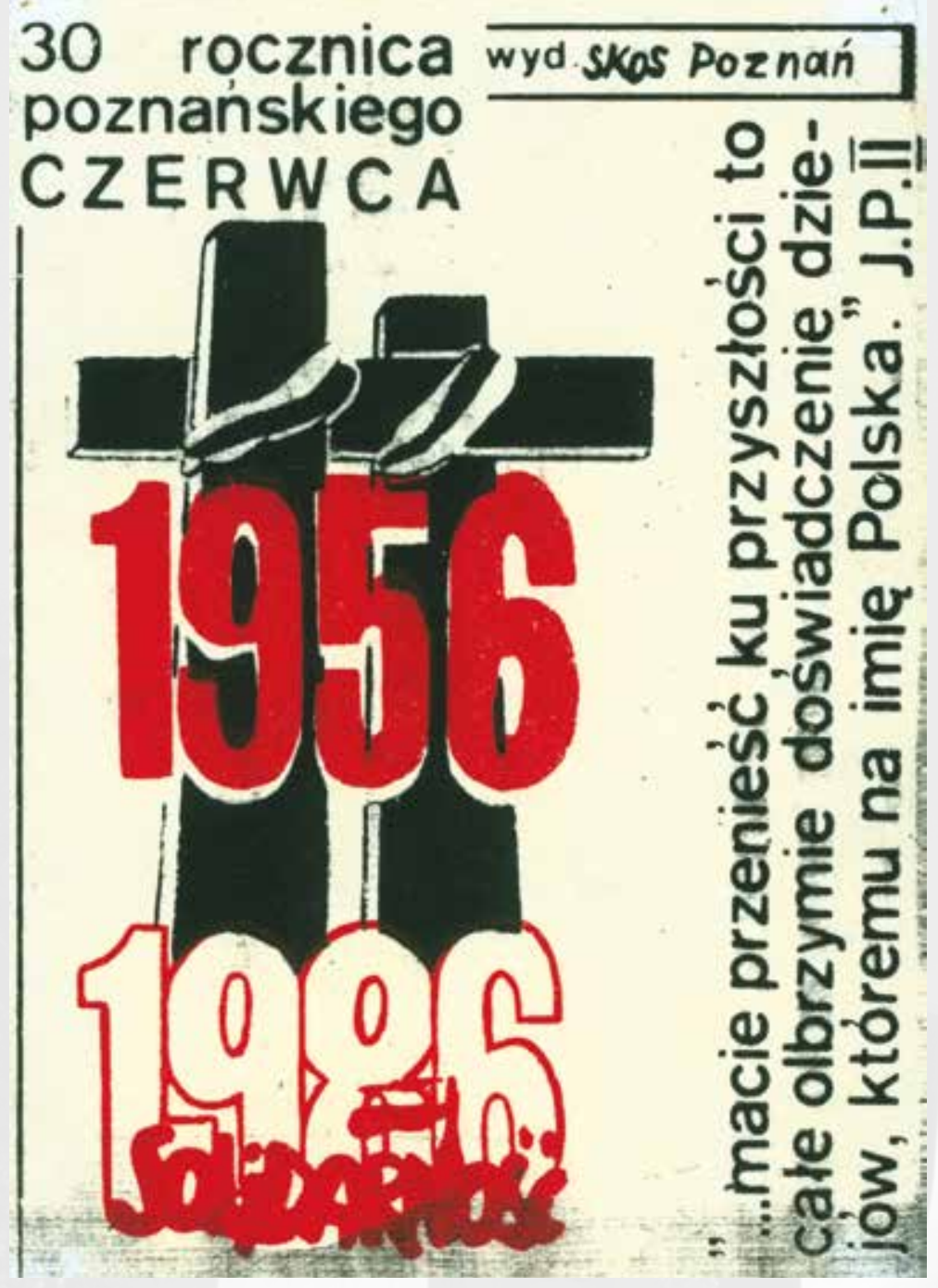

Kartka okolicznościowa wydana przez skos Poznań w trzydziestą rocznicę poznańskiego Czerwca '56 


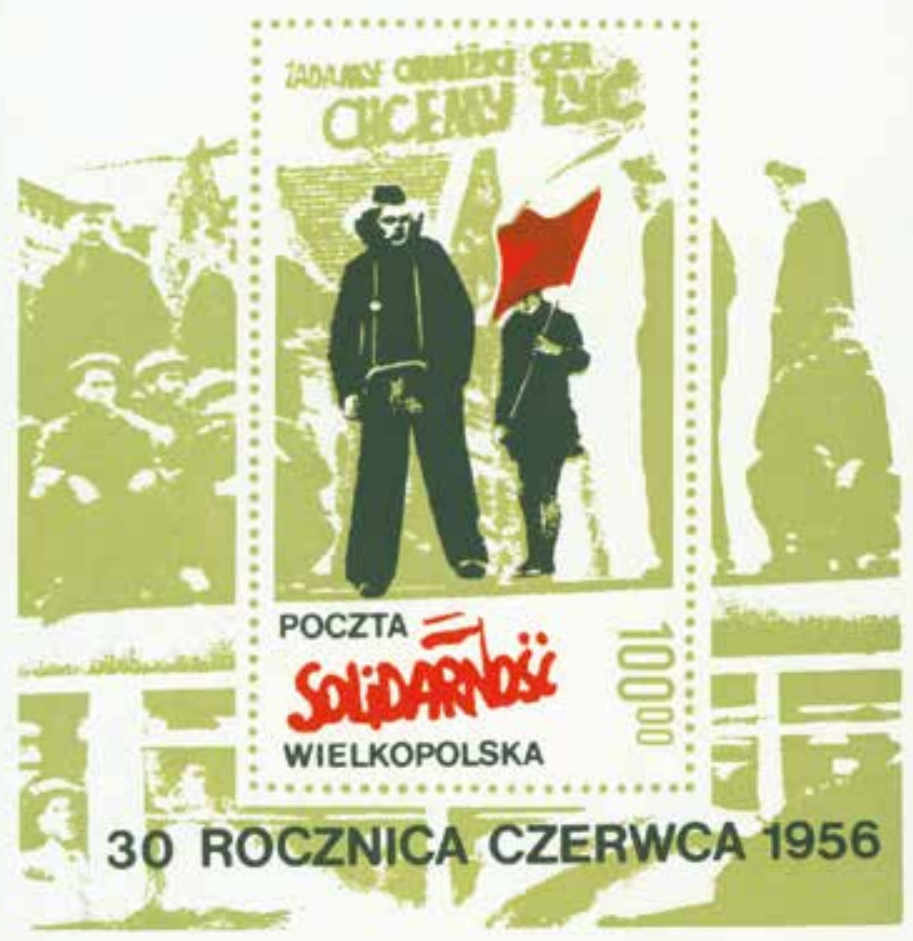

Kartka pocztowa wydana przez zrzeszonych w NSzZ „Solidarność” pocztowców z Wielkopolski w trzydziestą rocznicę poznańskiego Czerwca '56 
